\title{
ECOLOGY AND DISTRIBUTION OF DICRANUM VIRIDE (SULL. \& LESQ.) LINDB. (BRYOPHYTA) IN THE SOUTHERN URAL MTS.
}

\author{
ЭКОЛОГИЯ И РАСПРОСТРАНЕНИЕ DICRANUM VIRIDE (SULL. \& LESQ.) LINDB. \\ (BRYOPНYТА) НА ЮЖНОМ УРАЛЕ
}

\author{
ELVIRA Z. BAISHEVA ${ }^{1}$, ANNA MEŽAKA ${ }^{2}$, PAVEL S. SHIROKIKH ${ }^{1} \&$ VASILIJ B. MARTYNENKO $^{1}$ \\ ЭЛЬВИРА 3. БАИШЕВА ${ }^{1}$, АННА МЕЖАКА, ПАВЕЛ С. ШИРОКИХ ${ }^{1}$, ВАСИЛИЙ Б. МАРТЫНЕНКО ${ }^{1}$
}

Abstract

\begin{abstract}
Distribution and ecology of a rare red-listed bryophyte Dicranum viride were studied in nemoral and dark coniferous-nemoral forests of the western part of the Southern Urals. In total, data from 63 sample plots $(20 \times 20 \mathrm{~m})$ which were made in forests with different age structures were analyzed. Populations of Dicranum viride in the Southern Urals showed high vitality and were abundant on suitable substrates and habitats. The distribution of Dicranum viride was related to forest type, environmental factors and history of land management. Ecological scaling showed that Dicranum viride in the Southern Urals had a narrow ecological amplitude, especially in relation to the factor of continentality. Characteristic features for South Ural regions with Dicranum viride are diverse topography and mountain river valleys which represent refugia of a nemoral flora. This likely explains the occurrence of relict nemoral species (Dicranum viride, Eurhynchium angustirete, Brachythecium geheebii, Frullania bolanderi, Anomodon spp., Metzgeria furcata, Lejeunea cavifolia) with limited dispersal ability and sporadic distribution in the European part of Russia. Besides, good preservation of Dicranum viride populations in the Southern Urals is due to historical factors related to specific forest management practices in this region during the $18^{\text {th }}-20^{\text {th }}$ centuries.
\end{abstract}

Резюме

Обсуждаются распространение и экология редкого краснокнижного вида Dicranum viride в неморальных и темнохвойно-широколиственных лесах западной части Южного Урала. В основу работы положены данные анализа 63 пробных площадей $(20 \times 20$ м), заложенных в лесах разного возраста. Южно-уральские популяции Dicranum viride имеют высокий виталитет и обилие в подходящих для вида местообитаниях. Выявлена зависимость распространения Dicranum viride от типа леса, условий окружающей среды и истории хозяйственного освоения территории. Использование метода экологических шкал показало, что Dicranum viride имеет узкую экологическую амплитуду, особенно в отношении фактора континентальности. Характерными местообитаниями вида являются долины горных рек, которые на Южном Урале являются рефугиумами неморальной флоры. Вероятно, именно в этих местах сохранились реликтовые неморальные виды (Dicranum viride, Eurhynchium angustirete, Brachythecium geheebii, Frullania bolanderi, Anomodon spp., Metzgeria furcata, Lejeunea cavifolia), которые имеют ограниченную способность к расселению и рассеянное распространение в Европейской части России. Существование хорошо cохранившихся популяций Dicranum viride на Южном Урале также связано со спецификой лесопользования в регионе в течении XVIII-XX вв.

KEYWORDS: Dicranum viride, bryophytes, rare species, nature conservation, nemoral forests, oldgrowth forests

\section{INTRODUCTION}

The Ural Mountains represent the natural border between Europe and Asia and show drastic differences in climate (wet versus dry), biomes, and resulting species distribution between the Western and Eastern sides of the Ural Mts. (Shklyaev, 1964; Atlas..., 2005). The South Urals not only represent the geographical border between Europe and Asia, but also the natural eastern limit of the nemoral forest distribution including species associated with these forests. This refers to rare species from different organism groups (bryophytes, invertebrates, vertebrates) in Bashkortostan (Gorchakovsky, 1972; Martynenko et al., 2005; Mirkin, 2010). Broad-leaved forests in the Southern Urals were noted as refugia (Krasheninnikov, 1939), as broad-leaved-Abies-Picea forests developed from pliocene nemoral vegetation (Ermakov et al., 2000).

1 - Institute of Biology, Ufa Research Centre of Russian Acad. Sci., October av., 69, Ufa, 450054 Russia - Россия 450054, г.Уфа, пр. Октября, д. 69, Институт биологии УНЦ РАН; e-mails: elvbai@mail.ru, shirpa@mail.ru, vasmar@anrb.ru

2 - Research Institute for Regional Studies, Rezekne Higher Education Institution, Atbrivosanas aleja 90, Rezekne, LV - 4601, Latvia; e-mail: anna.mezaka@ru.lv 
Dicranum viride is a rare nemoral species decreasing in abundance and it may be classified as an 'amphi-atlantic disjunct'. Disjunct distribution might be explained by the population history, as relicts from earlier times when species could show different distribution patterns could migrate under ecological conditions different from today (Dahl, 2007). This species is known from Central Europe, Norway, Baltic States, the Caucasus, European Russia, the southern part of the Far East, eastern parts of the USA and Canada.

Dicranum viride is a key bryophyte species with international conservation importance (Council Directive..., 1992). It has a scattered distribution in European Russia, except for the Southern Urals, and in southern part of West Siberia (Red Data Book..., 1995; Ignatov \& Ignatova, 2003; Ignatova \& Fedosov, 2008). The species is listed under the Bern Convention (Annex 2), in the European Bryophyte red-list noted as vulnerable (Red Data Book..., 1995) and in Annex 2 of the European Habitat Directive (Council Directive..., 1992). In regional Russian Red Books, it is listed as vulnerable in Krasnodar Territory (Ignatova, 2007), Republic of Komi (Zheleznova \& Shubina, 2010), Voronezh region (Red Data book..., 2011), Kursk region (Zolotukhin et al., 2001), Tver region (Zykov et al., 2002) and listed as a rare species in Belgorod region (Red Data Book..., 2004), Moscow region (Ignatov, 1998), Tula region (Red Data Book..., 2010), ) and the Republic of Bashkortostan (Baisheva, 2011).

Dicranum viride is a dioicous species found to be mostly dispersed asexually by leaf fragments and rarely by spores (Ignatov \& Ignatova, 2003). Therefore species with dominant dispersal by fragmentation have more limited dispersal, as leaf fragments cannot disperse as far as spores (Hallingbäck, 2002; Soderström et al., 2007). This species is susceptible to various threats (Ladle, Whittaker, 2011) such as forest cutting, and is therefore a good model organism to characterize the historical management and conservation in nemoral forests.

Several studies exist on distribution and taxonomy of Dicranum viride in Europe and in the United States of America (Erzberger, 1999; Hedenäs \& Bisang, 2004; Maslovsky, 2005; Ignatova \& Fedosov, 2008), but ecological studies (Sauer \& Preußing, 2003), especially at the Eastern limits of this species, are lacking.

The aim of the present study was to characterize the environmental and historical factors affecting distribution of Dicranum viride in the Southern Urals and to evaluate the conservation significance in vegetation communities where this species was found.

\section{MATERIALS AND METHODS}

In 1991-2010, the vegetation sampling was performed in a mountain-forest zone of Southern Ural. Relevé sites were selected subjectively in order to represent the typical forests in the region. The $20 \times 20 \mathrm{~m}$ plots were picked out to represent larger areas with homogeneous forest vegetation. In each plot, a list of all vascular plants and bryophytes was made, and the cover of each species growing on soil was evaluated according to Braun-Blanquet scale (Braun-Blanquet, 1964). For bryophytes, all substrates (tree trunks, dead wood, rocky substrate, etc.) were described.

The communities with Dicranum viride were revealed only in three regions: 1 - upper course of Rivers Bol'shoi and Malyj Inzer, 2 - valleys of Belaya and Nugush Rivers, 3 - Ufa plateau (Fig. 1). Regions 1 and 2 are located in the nemoral forest belt on the western slope of the Southern Urals, region 3 is located in the nemoral-coniferous forest belt of the Mountain forest region. Nemoral forests in the present study refer to broad-leaved forests. The data on location of relevés, tree stand composition, cover of layers, and forest age are given in Appendix 1.

The climate of the study area is continental with moderately warm, sometimes hot summer and long cold winter. The western part of the South Ural Mts. are the warmest and wettest regions in Bashkortostan. The average temperatures here are $-15,5--16,0{ }^{\circ} \mathrm{C}$ in January, and $+16,5-+18,5^{\circ} \mathrm{C}$ in July, the annual rainfall is $550-650$ $\mathrm{mm}$. The average snow cover is $50-70 \mathrm{~mm}$ (Atlas..., 2005).

A set of 63 phytosociological relevés of forest communities including Dicranum viride was placed into phytosociological database, managed in TURBOVEG (Hennekens \& Schaminee, 2001). For each sample plot, the importance of ecological factors was evaluated using the Landolt Scale (Landolt, 1977) (Fig.2). All species of vascular plants and bryophytes found in th esample plots were included in data analysis. The ecological factors were F (Humidity) - characterizing average soil humidity during the vegetation period, $\mathrm{R}$ (Reaction) - acidity of soil, $\mathrm{N}$ (Nutrient) - the richness of soil with mineral elements, $\mathrm{H}$ (Humus) - humus saturation in soil. L (Light) - preference to light, T (Temperature) - the average temperature requirements in places during the vegetation period. K (Continentality) - the differences in temperature and air humidity during the day or year.

For comparison with Dicranum viride, the importance of ecological factors was evaluated for two widespread epiphytic species, Dicranum montanum (data from 734 sample plots) and Pylaisia polyantha (320 sample plots), and two nemoral species, Neckera pennata (53 sample plots) and Homalia trichomanoides (24 sample plots) (Fig.2).

Classification of vegetation into associations were conducted by the JUICE programme package (Tichý et al., 2011). Detrended Correspondence Analysis (DCA) was used for finding relationships among communities (63 sample plots) and environmental factors (humidity, continentality, light, temperature, nutrient). DCA was conducted in the CANOCO 4.5 (ter Braak \& Šmilauer, 2002) programme package. All data (63 sample plots) relating to vascular plants and bryophytes, and ecological factors are included in Figure 3. 


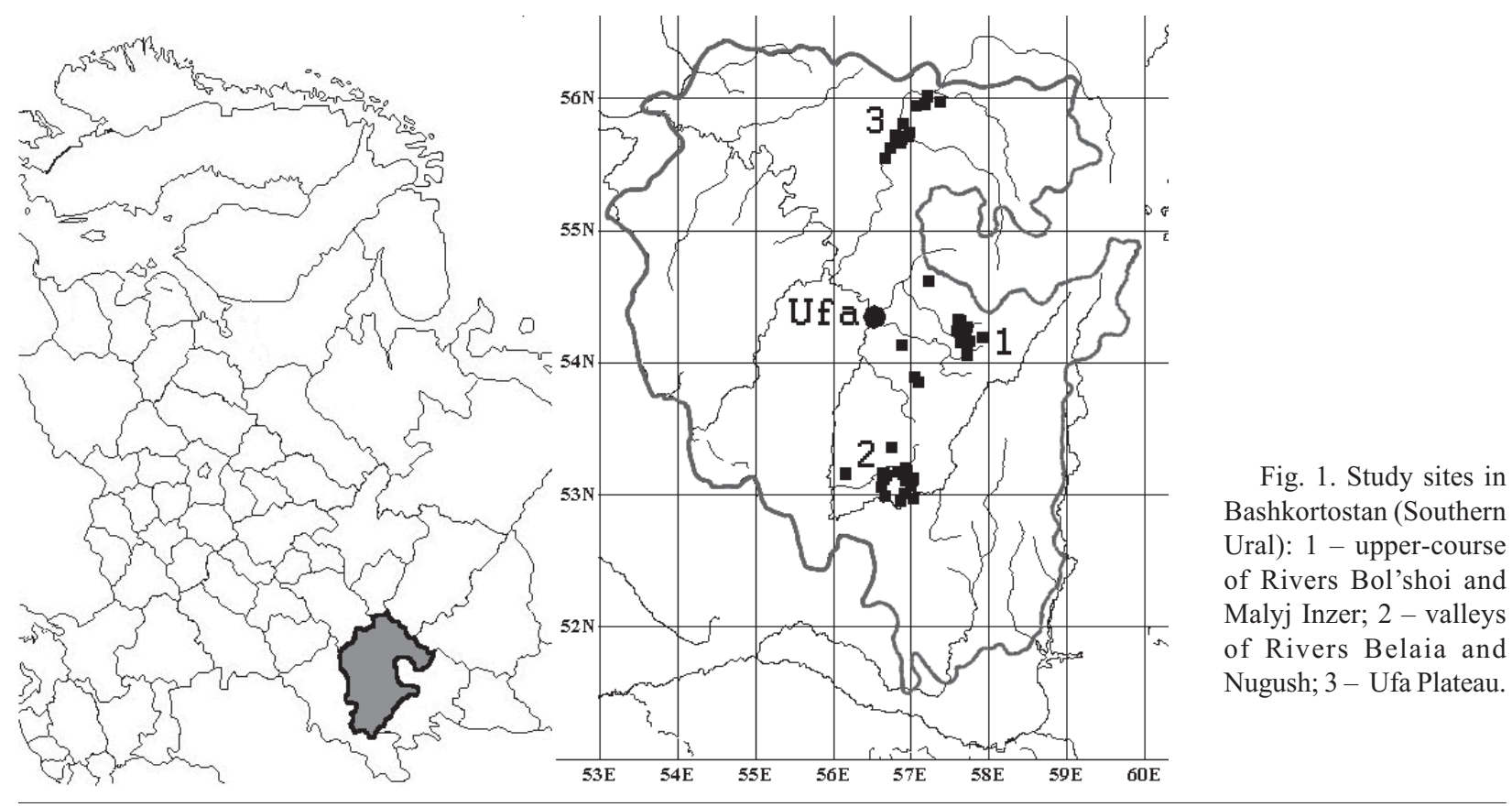

Determination of communities important for Dicranum viride conservation was based on expert evaluation. At first, the community received expert evaluation according to six basic criteria. Based on this evaluation, integral rates were identified - category of conservation and threat of dissappearence. Methods for plant communities evaluationwere developed during the preparation of the 'Green Book' (a summary of plant communities which are rare and in need of conservation) (Didukh, 2009; Bulokhov, 2012).

Species names follow the list of vascular plants of the former USSR (Cherepanov, 1995), the check-list of mosses of Eastern Europe and Northern Asia (Ignatov, Afonina, Ignatova et al., 2006) and the check-list of liverworts (Marchantiophyta) of Russia (Konstantinova, Bakalin et al., 2009).

\section{RESULTS}

In Bashkortostan Dicranum viride was found in nine forest vegetation associations (Appendix 1). The dominant tree species in the studied forests were Tilia cordata, Acer platanoides, Ulmus glabra, U. laevis, Quercus robur, Abies sibirica, Picea abies, P. obovata, Betula pendula, Populus tremula, and Padus avium; the shrub layer was represented by Rubus idaeus, Rosa majalis, Lonicera xylosteum and Euonymus verrucosa; the herb layer was composed mainly of Asarum europaeum, Galium odoratum, Calamagrostis arundinacea, Lathyrus vernus, Rubus saxatilis and Stellaria holostea. A fragment of the synoptic table of investigated communities is given in Appendix 2.

Most of the study plots $(>70 \%)$ were made in forests of uneven age structure, about $17 \%$ of studied forest communities were mature (forest age $>70$ years) and overmature (forest age $>100$ years). The forests were characterized with high tree canopy cover $(60-85 \%)$.
The cover of epigeic bryophytes was up to $15 \%$ in nemoral forests and 10-15(-60)\% in nemoral-coniferous forests (see Supplement 1, http://arctoa.ru/ru/Archive-ru/ 19/Baisheva-supplement1.php).

The results of DCA showed that Dicranum viride was found more often in mesophytic nemoral and coniferous-nemoral forests (alliances Aconito-Tilion and Aconito-Piceion), sometimes the species was found in xeromesophytic Quercus robur forests as well as on separate broad-leaved trees in coniferous forests. The species was found in shady places with increased air humidity (Fig. 3). The main factor explaining axis 1 in relation to Dicranum viride communities is a complex gradient with increasing continentality and decreasing nutrient. Axis 2 is explained by decreasing light and increasing humidity in forest communities.

The analysis of ecological factors in the studied communities with Dicranum viride showed that $D$. viride has a narrow ecological amplitude (0.5-1.1 units of Landolt scale). Similar results were obtained for other nemoral species Homalia trichomanoides and Neckera pennata. In comparison with widespread epiphytic species Dicranum montanum and Pylaisia polyantha, the nemoral species were particularly sensitive to continentality (Fig. 2).

A system of criteria, consisting of community rarity, characteristics of floristic composition (species richness, presence of rare species), succession stage, a tendency towards decreasing distribution was used for evaluation of forest community conservation significance, where $\mathrm{Di}$ cranum viride was found (Tab. 1). The system of criteria presented below was originally prepared in the Geobotanical and Vegetation Protection Laboratory, Institute of Biology of Ufa Research Centre of RAS (Martynenko, 2009). 

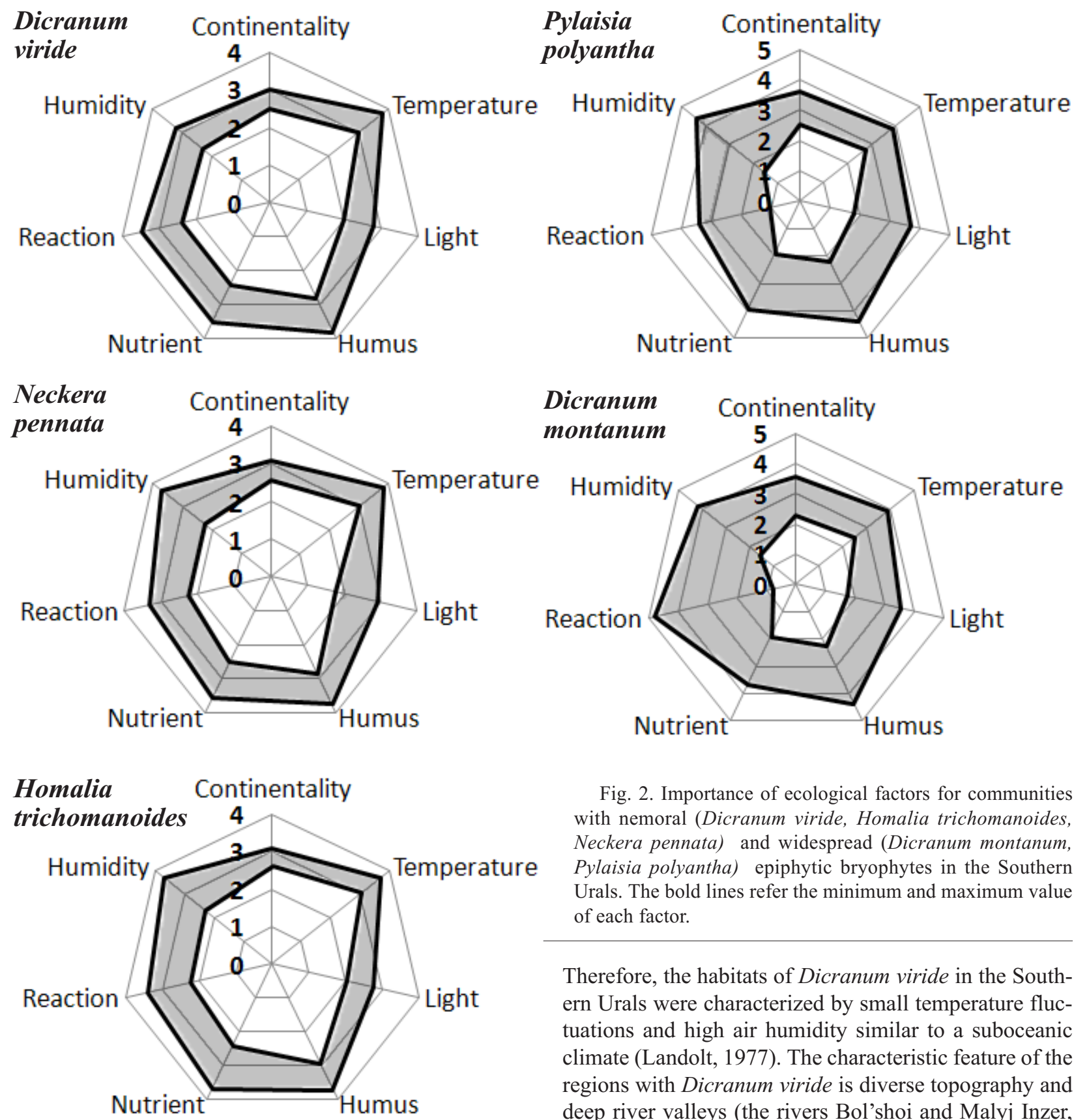

Fig. 2. Importance of ecological factors for communities with nemoral (Dicranum viride, Homalia trichomanoides, Neckera pennata) and widespread (Dicranum montanum, Pylaisia polyantha) epiphytic bryophytes in the Southern Urals. The bold lines refer the minimum and maximum value of each factor.

Therefore, the habitats of Dicranum viride in the Southern Urals were characterized by small temperature fluctuations and high air humidity similar to a suboceanic climate (Landolt, 1977). The characteristic feature of the regions with Dicranum viride is diverse topography and deep river valleys (the rivers Bol'shoi and Malyj Inzer, Belaya, Nugush, Kuzha), having a stable microclimate.

Danukalova et al. (2009) noted that the main causes of flora development in the Southern Urals were absence of ice caps in different glacial periods of the Quaternary and changes of paleoenvironment as these were not as strong as in North Western European territories. In periods of regression phases and climate continentalization the plains underwent changes favouring development of steppe, but forest vegetation was preserved in river valleys during the Pleistocene (Smirnova, 2004). Therefore, valleys of mountain rivers in the Southern Urals contained the refugia of the nemoral flora. In our opinion, this is the reason for the occurrence of relict nemoral species (Dicranum viride, Eurhynchium angustirete, Brachythecium geheebii, Anomodon spp., Frullania bolanderi, Pylaisia selwynii, Metz- 


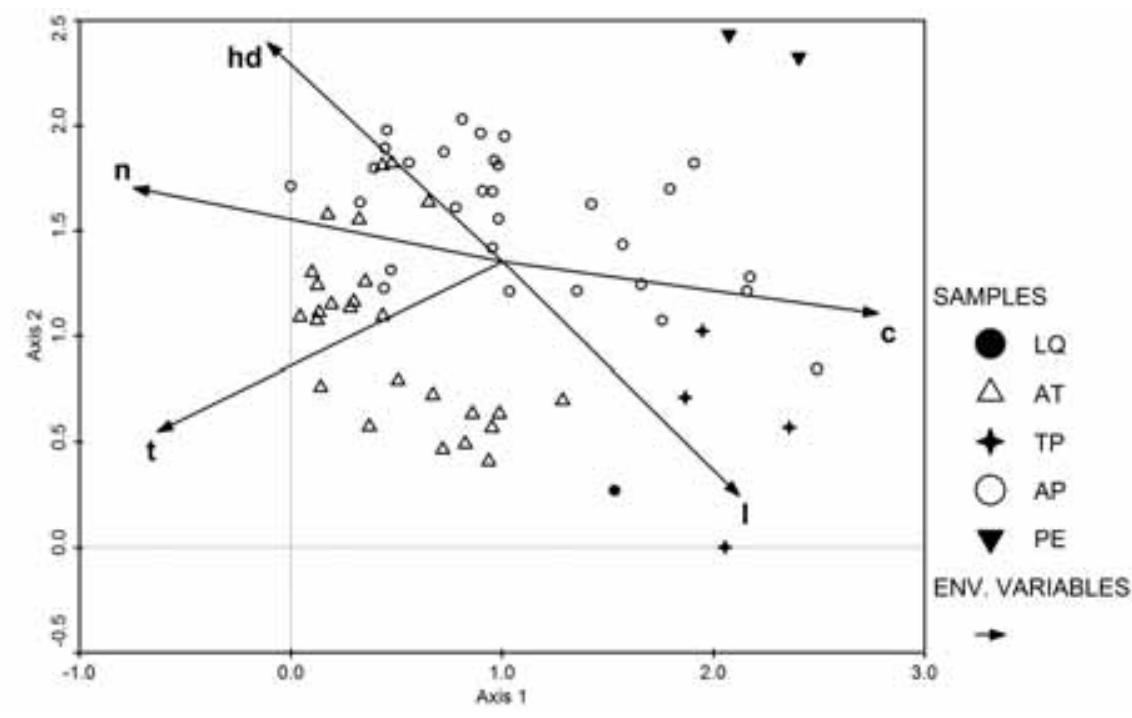

Fig. 3. DCA of forest communities including Dicranum viride in relation to ecological factors. Axis 1 explains $35 \%$ variation, $22 \%$ variation is explained by Axis 2. Community types - LQ - xeromesophytic, mostley grass Quercus robur forests (alliance Lathyro-Quercion), AT mesophytic nemoral forests (suballiance Aconito-Tilienion), TP - mesophytic Pinus sylvestris nemoral forests (suballiance TilioPinenion), AP - mesophytic coniferous-nemoral forests (alliance Aconito-Piceion), PE - mesophytic coniferous herbaceous-green moss forests (alliance Piceion excelsae). Ecological factors: hd - humidity, c - continentality, 1 - light, $\mathrm{t}$ - temperature, $\mathrm{n}-$ nutrients. geria furcata, and Lejeunea cavifolia in mountain river valleys. These species have limited dispersal ability and sporadic distribution in the European part of Russia.

Dicranum viride prefers specific forest types as it is related to particular substrate trees. It grows mostly on Tilia cordata trunks, sometimes is found also on other broad-leaved trees and recent dead-wood (Baisheva, 2011, 2012). It was more often found in mesophytic nemoral and coniferous-nemoral forests (Fig.3) and rarely in much drier habitats (Pinus sylvestris-nemoral or Quercus robur forests), indicating that relict nemoral plant communities (including substrate tree) are more important for it then just humidity. Communities with Dicranum viride in the Southern Urals represent the climax old-growth nemoral and coniferous-nemoral forests which have been highly influenced by man (decreasing area) and preserved only in small territories at a local scale. For stabilization of these communities at least 100 years are necessary.

Vegetative reproduction characteristic of Dicranum viride is more effective in stable conditions, when gene cloning is typical for plants with better adaptation ability (Longton, 2006). The survival and successful existence of Dicranum viride is possible only in habitats, where habitat disturbance (anthropogenic) was not long-term, ensuring habitat continuity (Norden \& Appelqvist, 2001). The basic threat to Dicranum viride populations existence is wide clear-cutting, limiting potential substrate tree occurrence and aeration (Baisheva, 2011).

The management history of Southern Ural forests is connected with traditions of the Bashkir people, who until the $17-19^{\text {th }}$ centuries were managed cattle, removing dead wood, practicing wild beekeeping (in trees) and collecting edible and medical plants (Portal, 1946). Only in the second half of the $18^{\text {th }}$ century the Bashkir forests started to be cut down in the lowlands, while mountain nemoral forests along the river valleys were less affected (Rekhenberg, 1852) due to the poor transport. In such regions the logging could be carried out only in the winter time. Some largest trees were selected for chopping and transported across the ice on the rivers. For bryophytes, the winter logging is less harmful then the summer one, because the ground layer and the bases of tree trunks are protected by snow cover. Moreover, the broadleaved trees in the South Ural mountain forests have small annual increment with small productivity (Gorchakovsky, 1968; Martynenko et al., 2005; Mirkin, 2010) and are of no interest for timber enterprises in contrast to coniferous forests.

The tradition of beekeeping was strong among the Bashkir people also during the Soviet time. More than $30 \%$ of Russian nemoral Tilia cordata forests are concentrated in Bashkortostan (Khairetdinov, 2004). Tilia cordata is the most common tree species in the Southern Ural nemoral forests and is also important for beekeeping (Gorchakovsky, 1968). At 1970-1980 a lot of South Ural Tilia cordata forests were classified as "nectar limetree forests" - the forests of high value for beekeeping. Clear-cutting is prohibited there and the age of selective logging exceeds $80-90$ years. Therefore, large areas (39.7\%) of modern Tilia cordata forests in Bashkortostan are mature and overmature (Sultanova, 2006).

An important component of nemoral forest conservation in the Southern Urals was the establishment of conservation areas, especially the "Shul'gan-Tash" Nature Reserve and "Bashkiria" National Park. Since 2012, these territories became UNESCO Biosphere Reserve Bashkirskij Ural (MAB 2012). At the present time, conservation of $70 \%$ of the studied plant communities with Dicranum viride is provided in Bashkortostan (Tab. 1).

In general we conclude, that the existence of well-preserved Dicranum viride populations in the Southern Urals is due to natural and historical factors related to specific forest management practices in Bashkortostan during the $18-20^{\text {th }}$ centuries. Conservation of nemoral landscapes in 
Table 1. Rarity criteria, significance and ensurance of plant community conservation with Dicranum viride

\begin{tabular}{|c|c|c|c|c|c|c|c|c|}
\hline Associations $\backslash$ Criteria & $\mathrm{F}$ & $\mathrm{R}$ & $\mathrm{N}$ & $\mathrm{D}$ & $\mathrm{V}$ & $\mathrm{P}$ & $\mathrm{T}$ & $\mathrm{C}$ \\
\hline \multicolumn{9}{|c|}{ Alliance Lathyro-Quercion roboris (LQ) } \\
\hline Brachypodio-Quercetum & F3 & R6 & $\mathrm{N} 2$ & D2 & V1 & $\mathrm{P} 1$ & $\mathrm{~T} 2$ & $\mathrm{C} 2$ \\
\hline \multicolumn{9}{|c|}{ Suballiance Aconito septentrionalis-Tilienion cordatae (AT) } \\
\hline Brachypodio-Tilietum & F3 & $\mathrm{R} 4$ & N1 & D2 & V1 & $\mathrm{P} 2$ & $\mathrm{~T} 3$ & $\mathrm{C} 3$ \\
\hline Stachyo-Tilietum & F3 & $\mathrm{R} 4$ & N1 & D2 & V1 & $\mathrm{P} 2$ & $\mathrm{~T} 4$ & $\mathrm{C} 3$ \\
\hline \multicolumn{9}{|c|}{ Suballiance Tilio cordatae-Pinenion sylvestris (TP) } \\
\hline Tilio-Pinetum & F3 & R5 & $\mathrm{N} 2$ & D2 & V1 & $\mathrm{P} 2$ & $\mathrm{~T} 3$ & $\mathrm{C} 3$ \\
\hline \multicolumn{9}{|c|}{ Alliance Aconito septentrionalis-Piceion obovatae (AP) } \\
\hline Violo-Piceetum & $\mathrm{F} 1$ & R7 & $\mathrm{N} 1$ & D3 & V0 & $\mathrm{P} 2$ & $\mathrm{~T} 2$ & $\mathrm{C} 1$ \\
\hline Frangulo-Piceetum & $\mathrm{F} 2$ & R6 & $\mathrm{N} 1$ & D2 & V1 & $\mathrm{P} 0$ & $\mathrm{~T} 3$ & $\mathrm{C} 2$ \\
\hline Chrysosplenio-Piceetum & $\mathrm{F} 2$ & R6 & N1 & D2 & V1 & $\mathrm{P} 0$ & $\mathrm{~T} 3$ & $\mathrm{C} 2$ \\
\hline Brachypodio-Abietetum & F3 & R6 & N1 & D2 & V1 & $\mathrm{P} 0$ & $\mathrm{~T} 3$ & $\mathrm{C} 2$ \\
\hline \multicolumn{9}{|c|}{ Alliance Piceion excelsae (PE) } \\
\hline Equiseto-Piceetum & $\mathrm{F} 1$ & R6 & N1 & D2 & V0 & $\mathrm{P} 0$ & $\mathrm{~T} 2$ & $\mathrm{C} 1$ \\
\hline
\end{tabular}

Explanations:

1. Floristic-phytocenotic significance (F) - indicator influenced by rare species (red-listed species, endemics, relicts, species on areal border), total species richness, unique plant communities (species from different taxonomical divisions, location close to areal). F1- very high, F2 - high, F3 - medium.

2. Rarity (R) - serves to characterise plant community distribution, being dependent on size of these plant areas and also occurrence in their area. For evaluation of rarity we used the scale made for plant species by Rabinowitz et al. (1986) and adapted for plant community rarity (Izco, 1998). R4 - area narrow, occurrence high, huge size of phytocenosis; R5 - area narrow, occurrence low, huge size of phytocenosis; R6 - area narrow, occurrence high, small size of phytocenosis; R7 - area narrow, occurrence low, small size of phytocenosis.

3. Naturalness $(\mathbf{N})$ - indicator showing the level of community deviation from its original state, influenced by anthropogenic factors up to full degradation. N1 - climax communities, N2 - natural forest.

4. Decrease of area in region (D) - an important indicator in the current state of the community and future trends under the same level of anthropogenic influence. D2 - 50-79\%, D3- 30-49\%.

5. Renovation ability (V) - ability of plant communities to return to the original state after removal of the natural or anthropogenical influence. The lowest ability is shown by relict communities, where renovation is practically impossible due to lack of suitable climatical conditions. V0 - no ability of restoration, V1 - for restoration necessary 100 years.

6. Conservation insurance $(\mathbf{P})$ - an important indicator, which evaluates the threat of community dissappearence. The evaluation is based on communities of present type, being under protection in the region. P $0-$ no conservation, P1 $-<20 \%$ of area under conservation, $\mathrm{P} 2-21-50 \%$ area under conservation.

7. Threat of dissappearence (T) - an important integral indicator evaluated mostly on criteria 2, 4, 5, 6 and factors that are threating the community at the present time. T2 - dissappearing, T3 - vulnerable, T4 - small risk of dissappearence.

8. Conservation category $(\mathbf{C})$ - an integral indicator, reflecting the status or need for plant community conservation. Evaluation based on criteria 1, 3, 7. C1 - the highest, C2 - high, $\mathrm{C} 3$ - medium.

the Southern Urals has international importance as they are hotspots for internationally rare species. Furthermore, $D i$ cranum viride in Western Europe survives in few localities of small extent due to the intensive historical forestry (Erzberger, 1999). However, in the Southern Ural Mts, Dicranum viride may represent one of the largest population in Europe, similar to those found in Slovenian beech forests (Ódor \& Dort, 2002) and therefore may serve as an important part of the conservation of this species internationally. Further investigations are necessary for comparison of $\mathrm{Di}$ cranum viride populations in different regions in Europe, as distribution of this species may be highly dependent on particular regional factors and historical habitat management.

\section{ACKNOWLEDGEMENTS}

We are grateful to David Long for improving the English of the manuscript. The present study has been supported by Russian Foundation for Basic Research (grant 13-04-01410-a) and partly funded by European Union grant Erasmus Mundus Action Triple I 2010/2011 for postdoctoral research.

\section{LITERATURE CITED}

[ATLAS OF BASHKORTOSTAN REPUBLIC. Yaparov, I. (ed.)] ATЛAC РЕСПУБЛИКИ БАШКОРТОСТАН. (ред. ЯПаров, И.) 2005. Уфа, ГУП ГРИ «Баикортостан» [Ufa, GUP GRI “Bashkortostan”]. 420 pp.

[BAISHEVA, Е.Z.] БАИШЕВА Э.3. 2011. Мхи. - [Mosses]. В кн.: Миркин Б.М. (ред.) Красная книга Республики Башкортостан. Т. 1. Растения и грибы. Уфа, Медиа-Принт [In: Mirkin, B.M. (ed.) Krasnaja kniga Respubliki Bashkortostan. T.1. Rastenija i griby. Ufa, Media-Print]: 263-289.

[BAISHEVA, E.Z.] БАИШЕВА Э.3. 2012. О флоре мохообразных мезофитных широколиственных лесов Южного Урала. - [On the bryophyte flora of the mesophytic broad-leaved forests in the Southern Urals Mts.] Известия Самарского научного иентра PAH. [Izvestia Samarskogo nauchnogo centra RAN] 14 (1/7): 1689-1692.

BRAUN-BLANQUET, J. 1964. Pflanzensoziologie. Grundzuge der Vegetationskunde. - Wien-New York, Springer-Verlag. 865 pp.

[BULOKHOV, A.D. (ed.)] БУЛОХОВ А.Д. (ред. ) 2012. Зеленая книга Брянской области: растительные сообщества, нуждающиеся в охране. - [Green Data Book of the Bryansk region: plant communities that are in need of protection] Брянск, ГУП «Брянское областное полиграфическое объединение [Bryansk, GUP "Bryanskoe oblastnoe poligraficheskoe ob'edinenie"]. 144 pp. 
[CHEREPANOV, S. K.] ЧЕРЕПАНОВ C.К. 1995. Сосудистые растения России и сопредельных государств. - [Vascular plants of Russia and adjacent countries]. Санкт-Петербург, Мир и семья [Sankt-Peterburg, Mir i sem'ya]. 990 pp.

CHYTRÝ, M., J. DANIHELKA, M. HORSÁK, M. KOČI, S. KUBEŠOVA, Z. LOSOSOVÁ, Z. OTÝPKOVÁ, L. TICHÝ, V. MARTYNENKO \& E. BAISHEVA 2010. Modern analogues from the Southern Urals provide insights into biodiversity change in the early Holocene forests of Central Europe. - J. Biogeogr. 37: 767-780.

COUNCIL DIRECTIVE 92/43/EEC OF 21 MAY 1992 ON THE CONSERVATION OF NATURAL HABITATS AND OF WILD FAUNA AND FLORA. 1992. - Official Journal of the European Communities L 206. 22/07/1992: 0007-0050.

DAHL, E. 2007. The phytogeography of Northern Europe (British Isles, Fennoscandia and adjacent areas). - Cambridge, Cambridge University Press, $297 \mathrm{pp}$.

DANUKALOVA, G., A. YAKOVLEV, P. KOSINTCEV, A. AGADJANIAN, L. ALIMBEKOVA, A. EREMEEV \& E. MOROZOVA 2009. Quaternary fauna and flora of the Southern Urals region (Bashkortostan Republic). - Quaternary International 201(1-2): 13-24.

[DIDUKH, Ya.P. (ed.)] ДІДУХ, Я.П. (ред. ) 2009. ЗЕЛЕНА КНИГА УКРАЇНИ. - [THE GREEN BOOK OF UKRAINE] Київ, Альтерnpec [Kijev, Al'terpres]. 448 pp.

ERMAKOV, N., J. DRING \& J. RODWELL 2000. Classification of continental hemiboreal forests of North Asia. - Braun-Blanquetia 28: 1-131

ERZBERGER, P. 1999. Distribution of Dicranum viride and Dicranum tauricum in Hungary. - Studia bot. Hung. 29: 35-47.

[GORCHAKOVSKY, P.L.] ГОРЧАКОВСКИЙ П.Л. 1968. Растения европейских широколиственных лесов на восточном пределе их ареала. - [The plants of European broad-leaved forests in the eastern border of theirs areal]. Труды Ин-та экологии растений и животных Уральского филиала АН СССР. Свердловск [Trudy Instituta ecologii rastenij i zhivotnykh Uralskogo filiala Academii nauk SSSR. Sverdlovsk] 59: 1-207.

[GORCHAKOVSKY, P.L.] ГОРЧАКОВСКИЙ П.Л. 1972. Широколиственные леса и их место в растительном покрове Южного Урала. - [The broad-leaved forests and their role in the vegetation of the Southern Urals] Москва, Наука [Mоscow, Nauka]. 147 pp.

HALLINGBÄCK, T. 2002. Globally widespread bryophytes, but rare in Europe. - Portugaliae Acta Biologica 20: 11-24.

HEDENÄS, L. \& I. BISANG 2004. Key to European Dicranum species. - Herzogia 17: 179-197.

HENNEKENS, S.M. \& J.H.J. SCHAMINEE 2001. TURBOVEG, a comprehensive data base management system for vegetation data. $-J$. Veg. Sci. 12: 589-591.

[IGNATOV, M.S.] ИГНАТОВ М.C. 1998. Dicranum viride. - В кн.: Зубакин, В.А., В.Н. Тихомиров (ред.). Красная книга Московской области. Москва: Аргус, Русский университет [In: Zubakin, V.A., V.N. Tikhomirov (eds.). Red Data Book of Moscow Region. Moscow. Argus, Russkij universitet]: 484-485.

IGNATOV, M.S., O.M. AFONINA, E.A. IGNATOVA et al. 2006. Checklist of mosses of East Europe and North Asia. - Arctoa 15: 1-130.

[IGNATOV, M.S. \& E.A. IGNATOVA] ИГНАТОВ, М.С., Е.А. ИГНАTOBA 2003. Флора мхов средней части Европейской России. 1 Sphagnaceae-Hedwigiaceae. - [Moss flora of the Middle European Russia. 1. Sphagnaceae-Hedwigiaceae] Москва, КМК [Moscow, KMK]. $608 \mathrm{pp}$.

[IGNATOVA, Е.А.] ИГНАТОВА Е.А. 2007. Dicranum viride. - В кн. Акатов В. В., Т.В. Акатова, М.Г. Вахрамеева и др. Красная книга Краснодарского края (растения и грибы). 2-е изд. Краснодар, OOO «Дизайн-Бюро» № 1 [In: Akatov, V.V., T.V. Akatova, M.G. Vakhramejeva et al. Krasnaja kniga Krasnodarskogo kraja (rastenija $i$ griby). 2nd ed. Krasnodar, OOO “Dizain-Buro № 1'”: 301.

IGNATOVA, E.A. \& V.E. FEDOSOV 2008. Species of Dicranum (Dicranaceae, Bryophyta) with fragile leaves in Russia. - Arctoa 17: 63-83.
IZCO, J. 1998. Types of rarity of plant communities. - J. Veg. Sci. 9(5): 641-646.

[KHAIRETDINOV, A.F. (ed.)] ХАЙРЕТДИНОВ А.Ф. (ред.) 2004. Леса Башкортостана. - [Forests of Bashkortostan] Уфa: БГАУ [Ufa: $B G A U] .400 \mathrm{pp}$.

KONSTANTINOVA, N.A., V.A. BAKALIN et al. 2009. Checklist of liverworts (Marchantiophyta) of Russia. - Arctoa 18: 1-64.

[KRASHENINNIKOV, I.M.] КРАШЕНИННИКОВ И.М. 1939. Основные пути развития растительности Южного Урала в связи с палеогеографией севера Евразии в плейстоцене и голоцене. - [The main trends of vegetation evolution in the Southern Urals in connection with paleogeography of northern Eurasia in Pleistocene and Holocene] Советская ботаника [Sovetskaja botanika] 6-7: 67-99.

LADLE, R. J. \&, R. J. WHITTAKER 2011. Conservation Biogeography. -Oxford, Wiley-Blackwell, $320 \mathrm{pp}$.

LANDOLT, E. 1977. Ökologische Zeigerwerte zur Schweizer Flora. Veröff. Geobot. Inst. ETH, Stiftung Rübel, Zürich, 64: 1-208.

LONGTON, R.E. 2006. Reproductive ecology of bryophytes: what does it tell us about the significance of sexual reproduction.. - Lindbergia 31: 16-23.

MAB 2012. Biosphere Reserves - Learning Sites for Sustainable Development. [online] 14 (September 2012) [accessed 1 July 2013] Available at: <http://www.unesco.org/new/fileadmin/MULTIMEDIA/HQ/ $S C / p d f / s c \_m a b \_W N B R \_B R 2012 . p d f \geq$

[MARTYNENKO, V.B.] MAРTЫНЕНКО В.Б. 2009. Синтаксономия лесов Южного Урала как теоретическая основа развития системы их охраны. - [Syntaxonomy of Southern Urals forests vegetation as the basis for development of forests protection system] Дисс.... $\partial$-pa биол. наук. Уфа, Башгосуниверситет [PhD thesis, Ufa, Bashkir State University]. $495 \mathrm{pp}$.

[MARTYNENKO, V. B., S. M. YAMALOV, O. YU. ZHIGUNOV \& A. A. FILINOV] МАРТЫНЕНКО В. Б., С. М. ЯМАЛОВ, О. Ю. ЖИГУНОВ, А. А. ФИЛИНОВ 2005. Растительность государственного природного заповедника «Шульган-Таш». - [Vegetation of "Shulgan-Tash" Nature Reserve] Уфа, Гилем [Ufa, Gilem]. 272 рp.

MASLOVSKY, O. 2005. Rare and threatened bryophytes and proposal for an Eastern Europe Red Book. - Bol. Soc. Esp. Briol. 26-27: 47-54.

[MIRKIN, B.M. (ed.)] МИРКИН Б.М. (ред.) 2010.Флора и растительность национального парка “Башкирия» (синтаксономия, антропогенная динамика, экологическое зонирование). - [Flora and vegetation of "Bashkirija" National Park (syntaxonomy, antropogenic dynamics, ecological zoning.] Уфа, Гилем [Ufa, Gilem]. 512 pp.

NORDEN, B. \& T. APPELQVIST 2001. Conceptual problems of Ecological Continuity and its bioindicators. - Biodiversity and Conservation 10: 779-791.

ÓDOR, P. \& K. VAN DORT 2002. Beech dead wood inhabiting bryophyte vegetation in two Slovenian forest reserves. - Zbornik gozdarstva in lesarstva 69: 155-169.

PORTAL, R. 1946. Les Bachkirs et le gouvernement russe au XVIIIe siècle. - Revue des Études slaves XXII (1-4): 82-104.

RABINOWITZ, D., S. CAIRNS \& T. DILLON 1986. Seven forms of rarity and their frequency in the flora of the British Isles. - In: Soule, M.E. (ed.) Conservation biology. The Science of Scarcity and Diversity. Sunderland, Massachusetts, Sinauer Associates, Inc.: 182-204.

[RED DATA BOOK OF BELGOROD REGION (Prisnyj, A.V., ed.)] КРАСНАЯ КНИГА БЕЛГОРОДСКОЙ ОБЛАСТИ. (ред. ПриснЫЙ А.В.) 2004. - Белгород [Belgorod]. 532 pp.

RED DATA BOOK OF EUROPEAN BRYOPHYTES. 1995. - Trondheim, European Commitee for the Conservation of Bryophytes (ECCB). $291 \mathrm{pp}$.

[RED DATA BOOK OF TULA REGION: PLANTS AND MUSHROOMS. (Shcherbakov, A.V., ed.)] КРАСНАЯ КНИГА ТУЛЬСКОЙ ОБЛАСТИ: РАСТЕНИЯ И ГРИБЫ (ред. Щербаков А. В.) 2010. Тула, Гриф и К [Tula, Grifi K]. 393 рр.

[RED DATA BOOK OF VORONEZH REGION. Vol. 1. PLANTS. LICHENS. MUSHROOMS. (Agafonov, V.A., ed.)] КРАСНАЯ КНИГА 

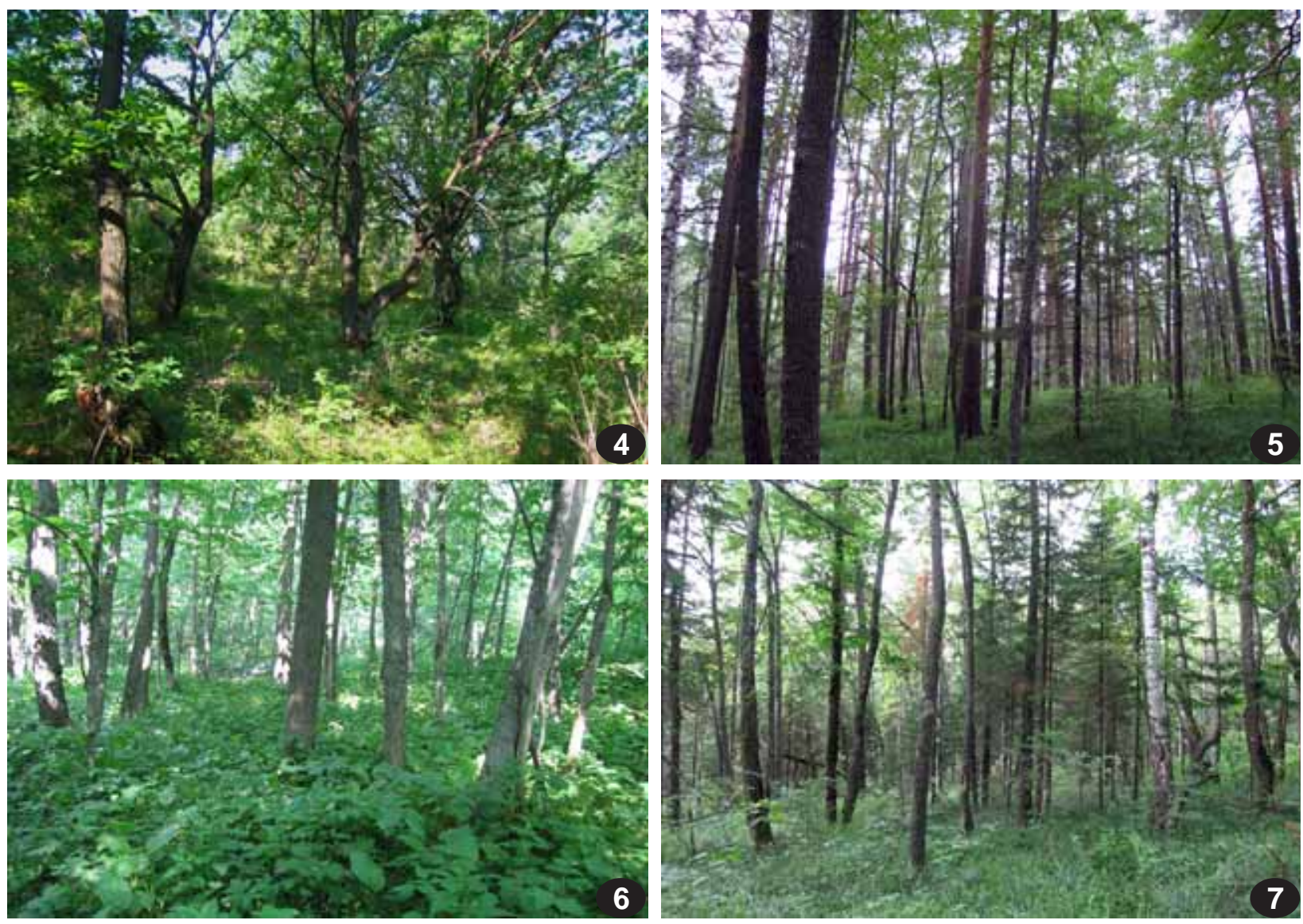

Figs. 4-7. Examples of Dicranum viride habitats in Lathyro-Quercion (4), Tilio-Pinenion (5), Aconito-Tilienion (6), AconitoPiceion (7).

ГРИБЫ. (ред. Агафонов В.А.) 2011. Воронеж,МОДЭК [Voronezh, Modek]. $472 \mathrm{pp}$.

[REKHENBERG, A.A.] PЕХЕНБЕРГ А.А. 1852. Статистическое описание лесного пространства между реками Уралом и Восточным Иком. - [Statistical description of forests between rivers Ural and Western Ik] Записки Императорского Русского географического общества. Санкт-Петербург [Zapiski Imperatorskogo russkogo geograficheskogo obshchestva. St. Petersburg] 6: 383-502.

SAUER, M. \& M. PREUßING 2003. Dicranum viride (Sull. \& Lesq.) Lindb. in Stuttgart. Beiträge zur Ökologie und Soziologie einer FFH. Art. - Limprichtia 22: 237-244.

[SHKLYAEV, A.S.] ШКЛЯЕВ А.С. 1964. Особенности распределения осадков и стока на Среднем и Южном Урале и их связь с атмосферной циркуляцией. - [The peculiarity of precipitations and flow distribution in the Middle and South Urals and their connection with atmospheric circulation] Ученые записки Пермского гос. ун-та [Uchenye Zapiski Permskogo gosudarstvennogo universiteta] 112: 3-108

[SMIRNOVA, O.V. (ed.)] СМИРНОВА О.В. (ред.) 2004. Восточноевропейские леса: история в голоцене и современность. Кн.1.[East European forests: Holocene history and the present. Vol.1.] Москва, Наука [Moscow, Nauka], 479 pp.

SÖDERSTRÖM, L., A. SÉNECA \& M. SANTOS 2007. Rarity patterns in members of the Lophoziaceae/Scapaniaceae complex occurring North of the tropics. Implications for conservation. - Biological Conservation 135: 352-359.
[SULTANOVA, R.R.] СУЛТАНОВА P.P. 2006. Лесоводственные методы формирования нектарных липняков на Южном Урале. - [Тhe forestry methods for growing of nectar lime-forests in the South Ural]. Автореф. дисс. ... д-ра с.-х. наук. Уфа, БГАУ [PhD thesis, Ufa, $B G A U] .39 \mathrm{pp}$.

TER BRAAK, C.J. \& P. ŠMILAUER. 2002. CANOCO Reference manual and CanoDraw for Windows User's guide: Software for Canonical Community Ordination (version 4.5). - Ithaca, Microcomputer Power. $500 \mathrm{pp}$.

TICHÝ, L., J. HOLT \& M. NEJEZCHLEBOVÁ 2011. JUICE. Program for management, analysis and classification of ecological data. $2^{\text {nd }}$ ed. Brno, Masaryk university. $61 \mathrm{pp}$.

[ZHELEZNOVA, G.V. \& T.P. SHUBINA] ЖЕЛЕЗНОВА Г.В., Т.П. ШУБИНА 2010. Dicranum viride. - В кн.: Красная книга Республики Коми (ред. Таскаев, А.И.). Сыктылвкар [In: Krasnaja kniga Respubliki Komi. Taskajev, A.I. (ed.). Syktyvkar]: 216.

[ZOLOTUKHIN, N.I., I.B. ZOLOTUKHINA, M.S. IGNATOV et al.] ЗОЛОТУХИН Н.И., И.Б. ЗОЛОТУХИНА, М.С. ИГНАТОВ и др. 2001. Красная книга Курской области. Т.2. Редкие и исчезающие виды растений и грибов. - [Red Data Book of Kursk Region. V.2. Rare and endangered species of plants and mushrooms]. Tyла [Tula]. $168 \mathrm{pp}$.

[ZYKOV, I.V., A.A. NOTOV \& U.N. SPIRINA] ЗЫКОВ И.В., А.А НОТОВ, У.Н. СПИРИНА 2002. Bryophyta. - В кн.: Красная книга Тверской области (ред. Сорокин, А.С.). Тверь, ООО «Вече Твери» [In: Krasnaja kniga Tverskoj oblasti. Sorokin, A.S. (ed). Tver, OOO "Veche Tveri"]: 10-35. 
APPENDIX 1

Syntaxonomical synopsis of forest communities with Dicranum viride in the Southern Urals

Class QUERCO-FAGETEA Br.-Bl. et Vlieger in Vlieger 1937

Order FAGETALIA SYLVATICAE Pawłowski, Sokołowski et Wallisch 1928

Alliance LATHYRO-QUERCION ROBORIS Solomeshch et al. 1989

Ass. Brachypodio pinnati-Quercetum roboris Grigorjev in Solomeshch et al. 1989

Alliance ACONITO SEPTENTRIONALIS-TILION CORDATAE Solomeshch et al. 1993

Suballiance Aconito septentrionalis-Tilienion cordatae Martynenko 2009

Ass. Brachypodio pinnati-Tilietum cordatae Grigorjev ex Martynenko et Zhigunov in Martynenko et al. 2005

Ass. Stachyo sylvaticae-Tilietum cordatae Martynenko et Zhigunov in Martynenko et al. 2005

Suballiance Tilio cordatae-Pinenion sylvestris Martynenko et Schirokikh 2009

Ass. Tilio cordatae-Pinetum sylvestris Martynenko 2009 prov.

Order ABIETETALIA SIBIRICAE (Ermakov in Ermakov et al. 2000) Ermakov 2006

Alliance ACONITO SEPTENTRIONALIS-PICEION OBOVATAE Solomeshch et al. ex Martynenko et al. 2008

Ass. Chrysosplenio alternifolii-Piceetum obovatae Martynenko et Zhigunova 2007

Ass. Frangulo alni-Piceetum obovatae Martynenko et Zhigunova 2007

Ass. Violo collinae-Piceetum obovatae Martynenko et Zhigunov in Martynenko et al. 2005

Ass. Brachypodio sylvatici-Abietetum sibiricae Martynenko et Zhigunova 2007

Class VACCINIO-PICEETEA Br.-Bl. in Br.-Bl., Siss. et Vlieger 1939

Order PICEETALIA EXCELSAE Pawłowski, Sokołowski et Wallisch 1928

Alliance PICEION EXCELSAE Pawłowski, Sokołowski et Wallisch 1928

Ass. Equiseto scirpoidis-Piceetum obovatae Martynenko et Zhigunova 2004

APPENDIX 2

Synoptic table of communities with Dicranum viride in the Southern Urals (species with low constancy are not shown)

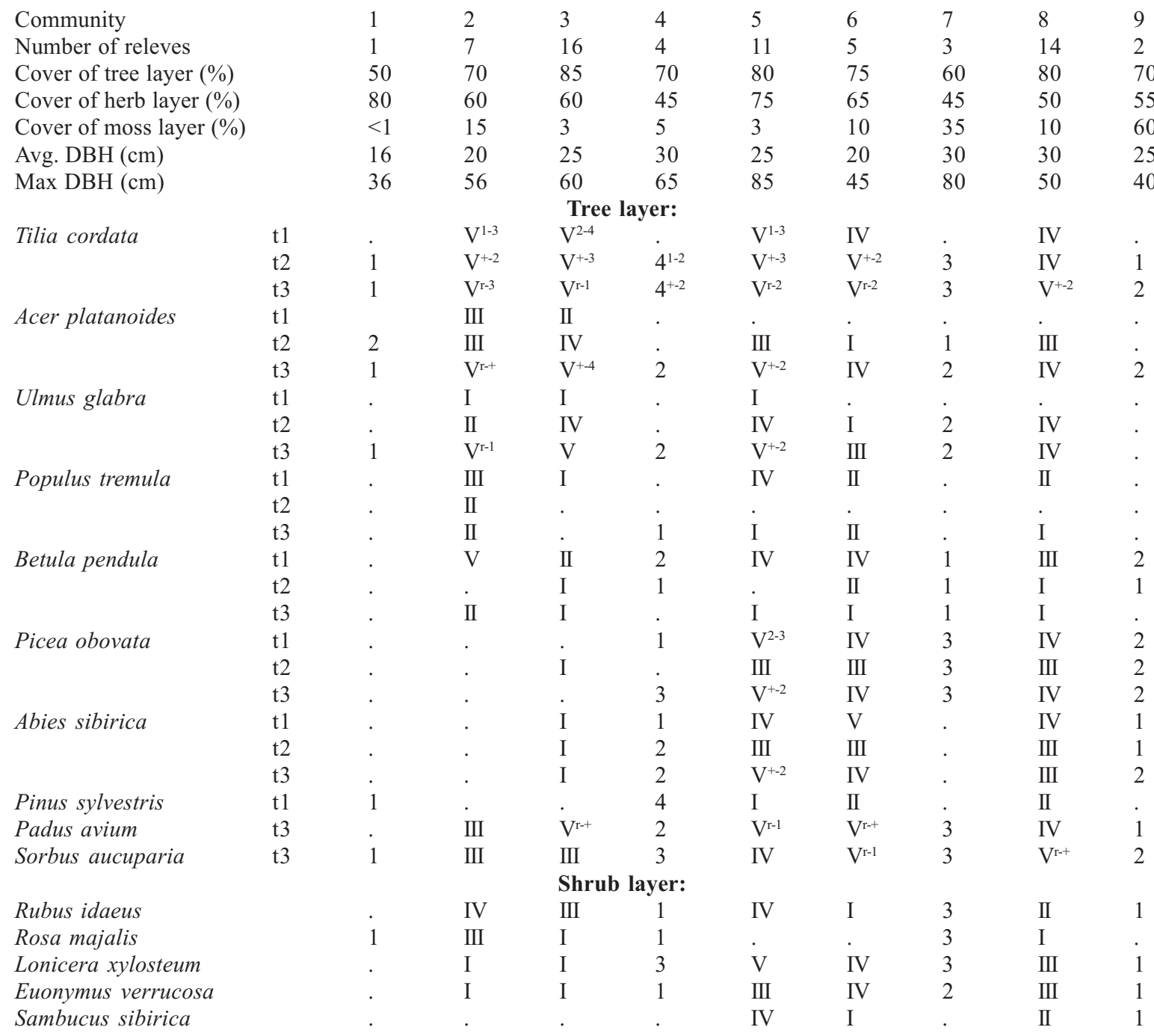


Aegopodium podagraria

Asarum europaeum

Galium odoratum

Calamagrostis arundinacea

Lathyrus vernus

Rubus saxatilis

Stellaria holostea

Aconitum lycoctonum

Crepis sibirica

Cicerbita uralensis

Dryopteris filix-mas

Pulmonaria obscura

Milium effusum

Viola mirabilis

Dicranum viride

Pylaisia polyantha

Pseudoleskeella nervosa

Platygyrium repens

Neckera pennata

Leucodon sciuroides

Anomodon longifolius

Orthotrichum speciosum

Homalia trichomanoides

Brachythecium salebrosum

Sciuro-hypnum reflexum

Dicranum montanum

Stereodon pallescens

Radula complanata

Callicladium haldanianum.

Amblystegium serpens

Lophocolea heterophylla

Sanionia uncinata

Ptilidium pulcherrimum

Plagiomnium cuspidatum

Eurhynchium hians

Fissidens taxifolius

Dicranum scoparium

Pleurozium schreberi

Rhytidiadelphustriquetrus

Rhodobryum roseum

Hylocomium splendens

Ptilium crista-castrensis

Paraleucobryum longifolium

Hypnum cupressiforme

Homomallium incurvatum

Tortella tortuosa

Eurhynchiastrum pulchellum

Campyliadelphus chrysophyllus

Explanations: 1: DBH - diameter of the trees at breast height.

2: $\quad \mathrm{t} 1, \mathrm{t} 2, \mathrm{t} 3$ - tree layers (from high to low).

3: Community: 1 - ass. Brachypodio pinnati-Quercetum roboris, 2 - ass. Brachypodio pinnati-Tilietum cordatae, 3 - ass. Stachyo sylvaticae-Tilietum cordatae, 4 - ass. Tilio cordatae-Pinetum sylvestris, 5 - ass. Chrysosplenio alternifolii-Piceetum obovatae, 6 - ass. Frangulo alni-Piceetum obovatae, 7 - ass. Violo collinae-Piceetum obovatae, 8 - ass. Brachypodio sylvatici-Abietetum sibiricae, 9 - ass. Equiseto scirpoidi-Piceetum obovatae.

4: In the columns $2,3,5,6,8$ the constancy of species have been evaluated according to the following scale: I species presented in 1-20\% relevés of the given association, II - 21-40\%, III - 41-60\%; IV - 61-80\%, V - 81-100\%. In the columns 1, 4, 7, 9 the constancy of species corresponds with the number of relevés in which the species was found.

5: For species with high constancy in the association the abundance in the sample plots have given: $\mathrm{r}-\mathrm{ex}-$ tremely rare, + - cover not more than $1 \%, 1-1-5 \%, 2-5-25 \%, 3-25-50 \%, 4-50-75 \%, 5-75-100 \%$. 